\title{
Analisis Sistem Pendidikan Islam Berbasis Pesantren Anak-Anak Tahfiz Al-Qur'ân Raudhatul Falâh Bermi Gembong Pati Jawa Tengah
}

\author{
Ahmad Falah \\ Institut Agama Islam Negeri Kudus, Jawa Tengah, Indonesia. \\ ahmadfalah97@gmail.com
}

\begin{abstract}
Analysis Studi of Educational System in Institusional Traditional System (Pesantren) for children of memorization al-Qur'ân at Raudhatul Falâh Bermi Gembong Pati Central Java. This paper of research institutional system (pesantren) for children age 6/7 - 12 Th in Raudhatul Falah Bermi Gembong Pati Central Java. The fist program in institutional traditional system is memorization of al-Qur'ân $30 \mathrm{juz}$ and learning is basic school (madrasa) /MI Tahfiz Raudhatul Falâh Gembong Pati Central Java. Educational system in institutional traditional include of teacher qur'an and teacher in basic shool, student, material or curriculum, methods of memorization of qur'ân, insfrastructure and environment education is dominant factor in succesfull system education aspecially in institutional traditional (pesantren)
\end{abstract}

Keyword: educational system, institutional traditional memorization qur'ân for childern, Gembong Pati.

\begin{abstract}
Abstrak
Pembahasan penelitian ini bertujuan untuk mendiskripsikan dan menganalisis sistem pendidikan Islam yang ada di pesantren tahfidz al-Qur'an anak-anak Raudhatul Falah Bermi Gembong Pati yang meliputi tujuan, kurikulum dan metode pendidikan yang diterapkan
\end{abstract}


di pesantren khususnya dalam pembelajaran hafalan al-Qur'an. Ruang lingkup tulisan ini berkaitan dengan integrasi sistem pendidikan Islam yang diterapkan di pesantren dan di Madrasah Ibtidaiyah. Metode penelitian yang digunakan dalam penelitian ini adalah pendekatan kualitatif dengan diskripstif analitik, yaitu mediskripsikan kegiatan hafalan siswa di pesantren dan juga ketika siswa di madrasah dengan analisa bahwa siswa MI yang mondok di pesantren dengan menghafal al-Qur'an 30 juz, ternyata dapat dilakukan dan ditempuh siswa dalam waktu rata-rata 5-6 tahun bahkan kurang. Hasil yang dapat diperoleh adalah sistem pendidikan Islam yang diterapkan di pesantren membawa siswa khususnya anak yang berumur 6-12 tahun, putra dan putri dapat menghafal al-Qur'an dengan baik dan mudah begitu juga siswa dapat mengikuti pembelajaran yang ada di Madrasah Ibtidaiyah dengan baik dan berprestasi. Kesimpulan yang dapat ditarik dari pembahasan ini adalah sistem pendidikan Islam yang diterapkan di pesantren yang meliputi tujuan, kurikulum dan metode dapat mengantarkan anak meraih kesuksesan hafalan al-Qur'an dan kesuksesan belajar di sekolah formal.

Kata Kunci : Sistem Pendidikan, pesantren tahfiẓ al-Qur'ân anakanak, Gembong Pati.

\section{A. Pendahuluan}

Pendidikan merupakan cerminan masa depan dan katalisator pembaharuan suatu bangsa. Karena itu transformasi pendidikan ke arah peningkatan mutu, efisiensi dan efektifitas adalah sebuah keniscayaan (Hayat and Ali 2012:5). Bidang ini sangat penting untuk dipikirkan, karena dalam pengertian yang luas menyangkut upaya penyampaian, pengembangan dan peningkatan kualitas keberagamaan di kalangan umat Islam. Keberhasilan dalam bidang tersebut, pada akhirnya akan mempengaruhi kemajuan umat Islam dalam berbagai dimensi, begitu juga sebaliknya. Sebagian dari masyarakat Islam adalah anak, sebagai individu yang pada prinsipnya memiliki akal sehat yang dapat dan harus didorong dan diarahkan untuk mencari ilmu. Potensi tersebut memberi kemungkinan kepada anak untuk mengembangkan kepribadian dan akalnya yang dilatarbelakangi kesadaran berpikir yang dimiliki oleh anak.

Perkembangan kepribadian, akal pikiran dan potensi anak melalui fase-fase perkembangan tertentu. Anak membutuhkan 
bimbingan, pengajaran, pengendalian, kontrol dari orang tua dan pendidik. Hal ini dengan tujuan mempersiapkan perkembangan anak agar mampu berperan serta secara berkesinambungan dan pembangunan manusia yang berkembang terus dan mampu beramal kebajikan dalam arti berakhlak mulia selama dalam upaya mencari kebahagiaan di dunia dan akhirat. Dengan demikian, pendidikan terhadap anak dipandang sebagai salah satu dimensi yang memiliki peranan pokok dalam pembentukan manusia agar menjadi insan yang sempurna atau memiliki kepribadian utama.

Berdasarkan asumsi di atas, maka diperlukan adanya pendidikan anak yang dapat membantu menyelesaikan problem yang dihadapi masyarakat muslim dewasa ini, yaitu masih terdapat adanya dualisme sistem pendidikan di Indonesia, munculnya persekolahan yang melahirkan manusia-manusia yang menguasai ilmu pengetahuan umum, namun kurang mengetahui ilmu agama, ataupun sebaliknya. Selain itu gencarnya pengaruh modernisasi yang menuntut lembaga pendidikan formal untuk memberikan ilmu pengetahuan umum dan ketrampilan sebanyak-banyaknya kepada anak didik sebagai bekal bagi kehidupan mereka, yang banyak hal telah mendesak dan mengurangi kesempatan anak-anak muslim untuk memperoleh bekal keagamaan yang cukup memadai. Maka dari itu hendaknya pendidikan menyentuh seluruh aspek yang bersinggungan langsung dengan kebutuhan perkembangan individu anak, baik itu dari ilmu agama maupun ilmu umum agar mereka dapat hidup dan berkembang sesuai dengan ajaran Islam yang komprehensif. Salah satu jenis kelembagaan pendidikan yang dilaksanakan umat Islam Indonesia adalah pesantren. Pesantren didirikan atas dasar tafaqquh fi al-dîn yaitu untuk memperdalam ilmu pengetahuan agama Islam dengan menekankan pentingnya moral dan pengamalan ajaran Islam dalam hidup bermasyarakat (Muthohar 2007:17). Tujuan pendidikan pesantren adalah menciptakan dan mengembangkan kepribadian muslim, yaitu kepribadian yang beriman dan bertakwa kepada Allah Swt, berakhlak mulia, bermanfaat bagi masyarakat, sebagai pelayan masyarakat, mandiri, bebas dan teguh dalam kepribadian, menyebarkan dan menegakkan agama islam dan kejayaan umat islam di tengah-tengah masyarakat dan mencintai ilmu dalam rangka mengembangakan kepribadian Indonesia (Prayitno 2016:315). Salah satu pendidikan pesantren yang ada di Indonesia adalah pesantren 
tahfiz al-Qur'an. Pesantren tahfiz al-Qur'an dikategorikan menjadi pesantren tahfiz dewasa, remaja dan anak-anak. Dalam pembahasan tulisan ini akan diangkat tentang pesantren tahfiz anak-anak dengan sistem pendidikannnya di pesantren anak-anak tahfiz al-Qur'ân Raudhatul Falah dan di MI Tahfiz Raudlatul Falah di desa Bermi kecamatan Gembong kabupaten Pati.

Pesantren anak-anak tahfiz Raudhatul Falah Bermi Gembong Pati adalah sebuah pesantren khusus untuk anak usia 6 atau 7-12 tahun setingkat SD atau MI untuk anak laki-laki dan perempuan. Pendidikan utamanya adalah menghafal al-Qur'ân 30 juz dan diajarkan pula ilmu-ilmu agama seperti tajwid, tauhid, akhlak, hadits, fiqh, tarikh, aswaja, imla', khoth, nahwu shorof dan qiraatul kutub (Dokumentasi Pesantren Raudhatul Falah Bermi Gembong Pati 2016:71). Disamping itu anak-anak belajar di Madrasah Ibtidaiyah Raudatul Falah yang ada di dalam pesantren yang mengajarkan ilmu pengetahuan agama dan ilmu pengetahuan umum. Sungguh unik model pesantren Tahfiz anak dalam dunia pendidikan umat Islam di Indonesia. Dilihat dari segi usia santrinya, pesantren tersebut berbeda dengan jenis pesantren secara umum yang biasanya mengasuh santri remaja hingga dewasa. Dilihat dari status para santri yang pada umumnya masih memiliki orang tua, pesantren tersebut juga bukan semacam panti asuhan yatim piatu yang biasa dikenal. Dengan kehadiran dan keberadaan lembaga semacam pesantren anak-anak tahfiz al-Qur'ân tersebut diharapkan kelak akan muncul generasi muda muslim yang benar-benar memahami Islam sekaligus mempunyai kemampuan dan kesadaran untuk meratakan risalahnya di tengah masyarakat dengan bekal ilmu pengetahuan agama dan ilmu pengetahuan umum.

Dalam prosesnya penelitian ini akan memotret secara mendalam tentang sistem pendidikan di pondok pesantren anakanak tahfîz al-Qurân yang terintegrasi dengan pendidikan di MI yang dilihat dari sistem pendidikan yang dilaksanakan di pesantren dan madrasah. Adapun beberapa rumusan masalah yang ingin dipecahkan sebagai berikut : Bagaimana sistem pendidikan pondok pesantren anak-anak tahfiz al-Qurân anak-anak Raudhatul Falâh Bermi Gembong Pati Jawa Tengah? Secara umum, studi ini bertujuan untuk mencari data dan informasi yang kemudian dianalisis, 
ditata secara sistematis dalam rangka menyajikan gambaran yang semaksimal mungkin utuh tentang pesantren anak-anak tahfìz alQurân Raudhatul Falâh Bermi Gembong Pati Jawa Tengah dan dinamika sistem pendidikannya. Penelitian mengenai pesantren tahfiz al-Qur'an bagi anak-anak madrasah ibtidaiyah tergolong tidak banyak, sehingga pembahasan dalan tulisan ini akan menambah penelitian dan literatur yang berbicara tentang pesantren tahfiz alQur'an bagi anak-anak khususnya di MI.

Pesantren anak-anak tahfiz al-Qur'an Raudhatul Falah Bermi Gembong Kudus, adalah salah satu pesantren anak-anak tahfîz yang ada di Indonesia. Untuk mengetahui gambaran secara jelas dan menyeluruh terhadap proses pembelajaran di pesantren dan di madrasah. Alasan penentuan lokasi penelitian ini didasarkan atas pertimbangan geografis wilayah dan jenis pesantren yang mendidik anak putra dan putri. Dari segi geografis, pesantren anak-anak tahfîz al-Qur'an Raudhatul Falah Bermi Gembong Kudus terletak di pinggiran kota Pati di sebelah timur gunung muria Colo yang masih asri dengan pegunungan. Dilihat dari pengelolaan dan pendidikan, pesantren tahfiz anak-anak Raudlatul Falah Bermi Gembong Pati Kudus mengelola anak putra-putri yang menghafal di pesantren dan belajar di MI Tahfiẓ Raudlatul Falah. Pesantren anak-anak tahfîẓ alQur'an Raudhatul Falah Bermi Gembong Pati secara geografis terletak di wilayah perkampungan yang jauh dari kota. Lokasi pesantren ini berada di salah satu wilayah kecamatan Gembong kabupaten Pati, tepatnya di desa Bermi yang masuk wilayah Gembong.

Lokasi pesantren tahfîẓ al-Qur'ân anak-anak ini sangat strategis, karena berada di dekat pondok pesantren Raudlatul Falah Gembong Pati yang juga merupakan cikal bakal berdirinya pesantren ini. Secara sosial budaya, pesantren ini berada pada lingkungan masyarakat yang religius, sehingga dinamika sosial budaya pada masyarakat pesantren ini dijiwai oleh nilai-nilai yang bernafaskan Islam.

Melihat obyek penelitian dalam penelitian kualitatif ini adalah pesantren anak-anak tahfîz al-Qur'an Raudhatul Falah Bermi Gembong Pati dan semua yang terkait yaitu observasi partisipan dengannya, maka teknik pengumpulan data dalam penelitian ini di sini meliputi observasi, wawancara dan dokumentasi. Peneliti melakukan observasi ini untuk memperoleh data tentang proses pembelajaran di 
pesantren dan madrasah, sistem pendidikan pesantren. Keterlibatan peneliti dalam observasi ini dilakukan dengan pengamatan secara intensif dan komprehensif terhadap obyek penelitian, karena secara metodologis pengamatan mengharuskan keterlibatan peneliti secara optimal dari segi motif, kepercayaan, perhatian, perilaku tak sadar, kebiasaan dan sebagainya, pengamatan juga memungkinkan peneliti untuk melihat dunia sebagaimana yang dilihat oleh subyek penelitian, hidup pada saat itu, menangkap arti fenomena dari segi pengertian subyek, menangkap kehidupan budaya dari segi pandangan dan panutan para subyek pada waktu itu, pengamatan juga memungkinkan peneliti merasakan apa yang dirasakan dan dihayati oleh subyek. Begitu juga dengan pengumpulan data dengan independent interview. Independent interview yaitu pengumpulan data yang dilaksanakan dengan cara bertanya secara langsung kepada responden untuk mendapatkan informasi (Masri Singarimbun and Sofiyan 1989:192). Metode ini berfungsi untuk memperoleh data tentang sistem pendidikan di pesantren dan madrasah, target dan peningkatan hafalan bagi santri. Wawancara dilaksanakan secara bebas dan mendalam untuk memperoleh data yang tersembunyi sehingga diketahui bagaimana tingkat hafalan santri pada setiap setoran hafalan al-Qur'an. Pengumpulan data dengan cara wawancara ini, peneliti tujukan kepada informan terpilih atas dasar relevansi kewenangan dan kemampuan yang memiliki pengetahuan dan sikap yang relevan dengan tujuan untuk mengetahui sistem pendidikan pesantren. Peneliti dalam hal ini melakukan interview kepada pimpinan pesantren yaitu KH. Sohib, guru pesantren dan madrasah Kyai Muslim. Dokumentasi juga penting untuk pengumpulan data dan hal-hal lain berupa catatan yang menunjukkan upaya madrasah dalam melaksanakan pembelajaran tahfiz al-Qur'an di pesantren dan pembelajaran di madrasah melalui penelusuran dokumen-dokumen (Arikunto 1989:188). Peneliti telah mengadakan pelacakan informasi lewat dokumen itu antara lain buku pedoman pesantren tahfîz alQur'an anak-anak, dan profil pesantren tahfîz al-Qur'an anak-anak Bermi Gembong Pati. Dalam penelitian kualitatif tidak ada pilihan lain dari pada menjadikan manusia sebagai instrumen peneliti utama. Memposisikan peneliti sebagai bagian utama yang berperan sebagai instrumen dalam kegiatan penelitian sejalan dengan arah penelitian kualitatif. 
Pada dasarnya analisis data adalah sebuah proses mengatur urutan data, mengorganisasikannya ke dalam suatu pola, kategori, dan satuan uraian dasar sehingga dapat ditemukan tema dan rumusan kerja seperti yang disarankan oleh data (Moleong 2001:103). Adapun teknik analisis data dalam hal ini peneliti mengatur, mengurutkan, mengelompokkan, memberikan kode dan mengkategorisasikan data yang terkumpul baik dari catatan lapangan, komentar peneliti, biografi dan artikel. Dalam penelitian kualitatif data diperoleh dari jenis data yang diperoleh secara kualitatif.

Untuk melaksanakan analisis data kualitatif, maka perlu ditekankan beberapa tahapan dan langkah-langkah sebagai berikut, data collection. Tahapan pertama yang dilakukan adalah proses pengumpulan data. Pengumpulam data ini dilakukan dengan cara berperan aktif dan berinterkasi dengan objek penelitian. Tahapan ini juga melakukan wawancara mendalam dan dokumentasi. Sesuatu yang dilihat, didengar, dibaca dan dirasakan oleh peneliti dapat ditanyakan pada orang-orang yang berada di lokasi yang terkait dengan tema penelitian. Model ini akan banyak mendapatkan data, oleh karena itu semakin sering terjun ke lapangan maka semakin banyak data yang diperoleh. Semakin lama melakukan pengamatan dan dialog di lokasi penelitian akan semakin luas dan variatif data yang diperoleh. Dalam tahapan pengumpulan data ini, peneliti mengunjungi pesantren dan madrasah yang ada di Gembong Pati, mewawancarai pimpinan pesantren, guru pesantren dan madrasah. Dalam proses wawancara tersebut peneliti juga melakukan pengamatan secara cermat atas berbagai aktivitas mereka terutama yang terkait dengan pelaksanaan pembelajaran tahfiz di pesantren dan madrasah.

Langkah selanjutnya adalah data reduction. Koleksi data yang diperoleh dari wawancara, pengamatan dan dokumentasi, akan mampu mendapatkan data yang cukup banyak dan bervariasi. Data-data tersebut banyak memiliki persamaan dan kemipiripan dengan data-data yang lain. Selain itu, ada keberbedaan, bahkan ada yang penting dan tidak penting. Ada yang relevan dan tidak relevan. Karena itu dalam tahapan reduksi ini akan dilakukan penyortiran data dengan cara mengkategorikan dan mengelompokkan data yang lebih penting, bermakna dan relevan dengan permasalahan serta tujuan penelitian. 
Setelah reduksi data yaitu data display, tahapan ketiga ini merupakan proses penampilan data reduksi yang telah diseleksi dari sekian banyak data yang ada. Tahapan ini dimaksudkan untuk memudahkan pemahaman terhadap persoalan dan data yang telah terseleksi agar mudah dimengerti oleh dirinya sendiri dan orang lain, kemudian data ditampilkan dan disajikan secara sistematis. Datadata yang telah ditampilkan selanjutnya dianalisis kembali, baik oleh dirinya sendiri maupun orang lain, apakah sudah kredibel dan sesuai dengan harapan atau belum. Kalau dianggap belum memadai dan kurang banyak, maka dilakukan penelitian kembali ke lapangan untuk mendapatkan data-data yang dibutuhkan dan sesuai dengan alur penelitian. Dalam konteks ini Nasution mengungkapkan bahwa dalam penelitian kualitatif, analisis data harus dilakukan sejak awal. Data yang diperoleh dari lapangan segera dituangkan dalam bentuk tulisan dan dianalisis. Macam-macam cara dapat diikuti. Tidak ada satu cara tertentu yang dapat dijadikan pegangan bagi semua peneliti (Nasution 1988:129). Proses pengumpulan data, reduksi data dan penampilan data menjadi bagian yang tak terpisahkan dengan tahapan akhir ini yaitu penyimpulan. Hubungan dari tahapan-tahapan tersebut bersifat interaktif. Dengan demikian lanjutan dari ketiga proses diatas adalah penyimpulan atas penyajian data yang telah menampilkan data-data terseleksi. Proses ini merupakan jawaban atas persoalan yang dituangkan dalam permasalahan penelitian. Dalam proses ini pula diharapkan menjadi temuan yang dapat menggambarkan pelaksanaan pembelajaran tahfîz di pesantren berikut di madrasah.

\section{B. Pembahasan}

Aktifitas Pendidikan di Pesantren Anak-Anak Tahfiz Raudatul Falâh Bermi Gembong Jawa Tengah dimulai mulai jam 04.-04.20 santri bangun tidur dan terus mandi, dilanjutkan sholat subuh berjama'ah dan diteruskan dengan jam wajib tahfiz, kurang lebih satu jam santri wajib tahfiz dilanjutkan istirahat, makan pagi dan persekolah di MI, jam 07.00 jam wajib sekolah di MI, jam 09.00 jam istirahat diselai dengan sholat dhuha dilanjutkan pembelajaran di MI sampai pukul 12.00 untuk waktunya dilaksanakan sholat dhuhur berjama'ah dan dilanjutkan istirahat dan makan siang. Kemudian setelah santri selesai dari sekolah di madrasah dilanjutkan jam wajib tidur siang dan jam 15.15 dilanjutkan sholat ashar berjama’ah, jam 
15.30 diteruskan dengan jam wajib tahfizh sampai jam 17.00, saatnya santri istirahat, makan sore dan bermain. Jam 18.00-19.00 dilanjutkan jam wajib tahfiz sampai dilakasanakan sholat isya' berjama'ah, kemudian jam 19.20 dilanjutkan jam wajib tahfizh sampai jam 20.15 jam wajib belajar sekolah formal sampai jam 21.00 saatnya tidur malam (Dokumentasi 2016:32).

Pendidikan al-Qur'an yang dilaksanakan di lokal pesantren masing-masing siswa didampingi ustadz al-Qur'ân dengan perbandingan 1 ustadz mengajar al-Qur'ân kurang lebih 10-15 santri. Aktifitas pendidikan al-Qur'ân sehari-hari di lokal pesantren secara umum berjalan lancar, akan tetapi bukan berarti tidak ada masalah. Diantara hambatan yang muncul bersumber dari kekurang mampuan santri dalam menghafal al-Qurân maupun kemampuan menyelesaikan tugas-tugas madrasah.

Setelah ditelusuri santri yang mengalami hambatan belajar pada umumnya adalah mereka yang kurang mental serta modal dasar pemahaman Al-Qur'an. Hal ini disebabkan ketika pertama kali diterima sebagai santri pesantren tahfiz modal pemahaman bacaan alQư'ân masih dirasa kurang, sehingga anak yang demikian mengalami kesulitan untuk adaptasi di pesantren. Masih banyak kenyataan lain yang mewarnai aktifitas pendidikan santri sehari-hari di lokal pesantren, termasuk suasana dunia anak-anak yang tidak mungkin terlepas sama sekali dari kehidupan bermain walaupun dalam situasi belajar. Meski ada beberapa hambatan, namun studi ini mendapati dengan jelas bahwa inti aktifitas pendidikan al-Qur'ân sehari-hari di lokal pesantren adalah " belajar”. Jadi bukan bermain sambil berlajar, atau sebaliknya belajar sambil bermain, seperti berlaku di taman kanak-kanak pada umumnya (Waluyo 1988:1).

Mewujudkan tujuan pendidikan diperlukan adanya kesinambungan antara komponen-komponen pendidikan Islam. Selain tujuan, komponen lainnya seperti metode, media, kurikulum, evaluasi, guru, dan murid juga sangat menentukan keberhasilan dari Pendidikan Islam itu sendiri (Nugroho 2019:13). Pelaksanaan pendidikan yang dilaksanakan di pondok pesantren Tahfiz anak ini tentunya memiliki komponen-komponen penting yang mendukung kelancaran kegiatan yang mana komponen-komponen tersebut menjadi sistem pendidikan pesantren, antara lain: 


\section{Peserta didik}

Peserta didik yang menuntut ilmu di lembaga Pesantren Tahfiz al-Qur'ân Raudhatul Falâh Bermi Gembong Pati ini dikenal dengan sebutan santri. Santri mempunyai dua macam pengertian yaitu: (a) seorang muslim yang rajin menjalankan agamanya, (b) seorang yang menuntut ilmu pengetahuan di pondok pesantren (dokumentasi pesantren). Santri atau peserta didik yang ada di pesantren Raudlatul Falâh itu berbeda-beda dilihat dari kecerdasan dan kepandaian mereka, kelincahan mereka, kesungguhan, kedisiplinan mereka sehingga untuk menangani santri yang cerdas dan santri yang kurang agak berbeda, karena untuk menangani anak yang kurang, lemah atau pendiam tidak mau bergaul dengan teman-temannya membutuhkan waktu yang cukup lama dan kesabaran yang tinggi.

Adapun kriteria santri dilihat dari aspek usia bahwa usia anak yang diterima menjadi santri sangat berfariatif mulai umur 6/7 tahun sampai 12 tahun. Pada anak usia ini, mereka sudah mulai mengenal lingkungan utamanya lingkungan sekolah. Anak mulai memiliki perasaan tajam dengan ciri-ciri antara lain: bahasa sosial yang digunakan sebagai alat komunikasi antar teman dan orang lain mulai berkembang, yang sudah mulai mampu bertanya jawab, hayalan masih terus berkembang, mulai mampu mengerti dan mengenal simbol huruf, angka dan tanda baca. Anak mulai mampu membedakan warna, ukuran yang berlawanan, mengenal jumlah dan mulai berpkir logis, selanjutnya anak sudah mulai mampu berkarya sendiri, memecahkan masalah, mulai mampu membedakan sifat-sifat benda, memiliki dan mengenal dasar norma peraturan yang berlaku, mampu dialog, mampu meciptakan suatu kreasi suatu mainan, mulai mampu berpikir wajar.

Disamping itu semua anak usia 6/7 tahun secara psikologis adalah anak yang telah sampai pada masa yang berhubungan dengan kemasakan yaitu anak-anak yang dapat bekerja sama dalam kelompok dengan anak-anak lain dalam satu komunitas dan dapat menyesuaikan diri dengan teman-teman sebaya, dan anak sejak berumur 7 tahun tekanan kelompok menjadi lebih kuat dibandingkan dengan umur sebelumnya atau ketika anak sudah semakin tumbuh dan pengaruh teman sebaya biasanya lebih kuat dibandingkan dengan pengaruh guru atau orang tua (Hurlock 1997:252). 
Peserta didik pesantren anak-anak tahfiz al-Qur'ân Raudhatul Falâh Bermi Gembong Pati adalah anak-anak yang sedang dan memiliki kecerdasan. Karena memang dalam penerimaan santri baru yang ketat dan kompetitif yaitu melalui seleksi ujian penyaringan diantaranya yaitu: membaca ayat-ayat al-Qur'ân, hafalan surat wajib, hafalan surat pilihan, tes intelegensi dan pengetahuan agama. Sedangkan santri yang lemah atau kurang adalah santri yang dari awal masuk ke pesantren kurang dasar pengetahuan agamanyadan kurang memahami huruf-huruf al-Qứân atau memang yang sudah kelihatan tanda-tanda kelemahannya yaitu anak agak lesu, tidak bergairahdalam belajar, cenderung pendiam dan jarang bermain.

\section{Pendidik}

Dalam konteks pendidikan Islam "pendidik" sering disebut dengan murabbi, mu'allim, mu'addib, mudarris, dan mursyid. menurut peristilahan yang dipakai dalam pendidikan dalam konteks Islam, Kelima istilah ini mempunyai tempat tersendiri dan mempunyai tugas masing-masing. Murabbi adalah: orang yang mendidik dan menyiapkan peserta didik agar mampu berkreasi serta mampu mengatur dan memelihara hasil kreasinya untuk tidak menimbulkan malapetaka bagi dirinya, masyarakat dan alam sekitarnya. Mu'allim adalah: orang yang menguasai ilmu dan mampu mengembangkannya serta menjelaskan fungsinya dalam kehidupan, menjelaskan dimensi teoritis dan praktisnya, sekaligus melakukan transfer ilmu pengetahuan, internalisasi serta implementasi. Mu'addib adalah: orang yang mampu menyiapkan peserta didik untuk bertanggungjawab dalam membangun peradaban yang berkualitas di masa depan. Mudarris adalah: orang yang memiliki kepekaan intelektual dan informasi serta memperbaharui pengetahuan dan keahliannya secara berkelanjutan, dan berusaha mencerdaskan peserta didiknya, memberantas kebodohan mereka, serta melatih keterampilan sesuai dengan bakat, minat dan kemampuannya. Mursyid adalah: orang yang mampu menjadi model atau sentral identifikasi diri atau menjadi pusat anutan, teladan dan konsultan bagi peserta didiknya.

Dalam pelaksanaan proses pendidikan sehari-hari di Pesantren anak-anak banyak pihak yang dalam kenyataannya menjalankan fungsi atau berperan sebagai pendidik, masing-masing dengan posisi yang 
agak berbeda, kyai dalam struktur peran menempati posisi teratas, para pengurus pesantren, kemudian para ustadz al-Qurân yang mengajar di Madrasah Ibtidaiyah Tahfiz al-Qurân Raudhatul Falâh Bermi Gembong Pati, para murabbi (pengasuh) yang menjaga dan mengawasi serta yang mengontrol santri. Pendidik atau ustadz adalah merupakan faktor yang paling dominan dalam mencapai tujuan kegiatan belajar-mengajar, sehingga ekstensinya sangat dibutuhkan, karena kunci utama di dalam peningkatan kualitas pendidikan adalah mutu para pendidik atau gurunya (Tilaar 2000:14).

Ustadz atau pendidik al-Qur'ân yang mengajar di pesantren anak-anak tahfiz anak-anak Raudhatul Falâh Bermi Gembong Pati bukan sembarang ustadz yang langsung diterima sebagai pendidik, namun melalui beberapa syarat yang harus dipenuhi yaitu sebagai berikut: Hafal al-Qur'ân seluruhnya yaitu seluruhnya 30 juz dengan lancar dan benar telah disemak oleh Bapak KH. Shohib dan Kyai Muslim, berakhlak mulia, sebagai pengabdian para santri pondok dewasa Huffaz Yanbu' al-Qur'an Kajeksan Kudus kepada yayasan Arwaniyyah karena telah menimba ilmu di pondok Huffaz Yanbu' alQur'an Kudus dan mempunyai sifat mendidik.

\section{Tujuan Pendidikan}

Pendidikan merupakan usaha dan kegiatan yang sarat dengan tujuan. Kedudukan tujuan dalam pendidikan cukup strategis, karena selain memberikan panduan tentang karakteristik manusia yang ingin dihasilkan oleh pendidikan tersebut, sekaligus pula menentukan arah dan langkah-langkah dalam melakukan seluruh kegiatan dan proses penyelenggaraan pendidikan. Oleh karena itulah berbagai pembahasan dan penelusuran terhadap suatu sistem pendidikan seringkali mengalami kegagalan disebabkan mengabaikan kajian terhadap konsep-konsep tujuan pendidikan yang dicanangkannya. Sedangkan tujuan itu sendiri adalah hasil atau prediket yang diinginkan untuk dapat dicapai oleh subyek, dalam hal ini subyek yang dimaksudkan adalah versi pesantren dan versi santri.

Sebagaimana telah penulis kemukakan bahwa pesantren anak-anak tahfîz Raudhatul Falah Gembong Pati adalah merupakan lembaga pendidikan tahfiz al-Qur'an secara dini, untuk itulah pesantren menetapkan target-target yang harus dicapai oleh santri 
yang disesuaikan dengan tahapan sekolah formal (MI), adapun target-target itu adalah sebagai berikut: kelas I target yang ditetapkan dalah melancarkan bacaan dan menghatamkan bacaan secara bi al nazor minimal 3 kali serta menghafalkan juz 30 (juz 'amma), kelas I target yang ditetapkan adalah 5 juz yaitu mulai dari juz 1-5, kelas III target yang ditetapkan adalah santri mampu menghafal 6 juz yaitu dari juz 6 sampai juz 11, kelas IV target yang ditetapka adalah 6 juz yaitu dari juz 12-juz 17,kelas V target yang ditetapkan adalah 6 juz yaitu dari juz 18 - juz 23, kelas VI target yang ditetapkan adalah 6 juz dari juz 24-29. Dengan disusun dan dirincinya tujuan dengan targettarget seperti tersebut diatas, maka segala upaya akan difokuskan untuk mencapai sasaran sesuai target, dan meskioun target tersebut disusun dengan didasarkan pada strata pendidikan formal, dalam pelaksanaannya semua santri yang berjumlah sekarang 130 (tahun 2016/2017) dibagi menjadi berkelompok dengan didasarka pada frekwensi kelas santri di MI.

Bagi para santri, pada umumnya mereka menghafal alQứân di pesantren anak-anak tahfiz Raudlatul Falâh Gembong Pati tujuannya adalah sebagaimana diinginkan oleh wali santri yaitu agar menjadi anak muslim yang hafal al-Qurân, dapat memelihara dan mengamalkan al-Qur'ân. Tujuan pendidikan pesantren harus didukung dan ditopang oleh semua komponen yang lainnya, karena tujuan itu akan mampu mengarahkan semua aktifitas yang perlu dilakukan sehingga pencapaian tujuan adalah buah dari aktifitas.

Dengan mengacu pada tujuan pendidikan, maka tujuan utama dari pesantren anak-anak tahfiz anak-anak Raudlatul Falâh Bermi Gembong Pati adalah:1) untuk membina, mengembangkan dan meningkatkan para penghafal al-Qur'an kuantitasnya maupun kualitasnya. 2) mencetak kader-kader yang hafal al-Qur'an memehami dan mendalami isinya. 3) mencetak kader-kader muslim yang berpengetahuan luas baik pengetahuan agama maupun pengetahuan umum dan mempunyai akhlak yang mulia. 4) untuk menjaga kemurnian al-Qur'an dari berbagai bentuk perubahan.Itulah tujuan pendidikan pesantren anak-anak tahfiz al-Qur'ân Raudhatul Falâh Gembong Pati tujuan utama, disamping juga pendidikan madrasah yang akan mencetak seorang hafiz yang berpengetahuan luas. Karena pentingnya tujuan menghafal al-Qur'ân itu dilakukan sejak dini, 
dengan penanaman al-Qur'ân sejak dini maka diharapkan akan mendapat nilai-nilai keimanan dari al-Qur'ân sampai anak tersebut menjadi dewasa.

\section{Kurikulum Pendidikan}

Pengertian kurikulum pendidikan di sini dapat disebut dengan kumpulan bahan pelajaran, dan juga dapat diartikan sebagai sebuah dokumen perencanaan yang berisi tentang tujuan yang harus dicapai, isi materi dan pengalaman belajar yang harus dilakukan siswa, strategi dan cara yang dapat dikembangkan, evaluasi yang dirancang untuk mengumpulkan informasi tentang pencapaian tujuan, serta implementasi yang dirancang dalam bentuk nyata. Dengan demikian, pengembangan kurikulum meliputi penyusunan dokumen, implementasi dokumen serta evaluasi dokumen yang telah disusun (Sanjaya 2009:10).

Apabila kita berbicara mengenai kurikulum maka yang jelas didalam pengertian kita adalah sejumlah mata pelajaran, buku-buku sumber, baik buku-buku teks maupun buku pegangan untuk guru, buku-buku perpustakaan, alat-alat bantu proses belajar mengajar, proses evaluasi dan sebagainya.

Namun demikian kurikulum suatu lembaga pendidikan lebih dari suatu daftar mata pelajaran yang dituntut di dalam suatu jeni dan jenjang pendidikan. Di dalam pengertian yang luas, kurikulum berisi kondisi yang telah melahirkan suatu rencana atau program pelajaran tertentu, juga berkenaan dengan proses yang terjadi di dalam lembaga (proses pembelajaran), fasilitas yang tersedia yang menunjang terjadinya proses, dan akhirnya produk atau hasil dari proses tersebut. Ternyata keberhasilan suatu lembaga pendidikan dengan kurikulumnya ditentukan oleh banyak faktor. Dengan demikian dapat kita kemukakan suatu rumusan operasional mengenai kurikulum.

Kurikulum yaitu suatu keseluruhan program, fasilitas, dan kegiatan suatu lembaga pendidikan untuk mewujudkan suatu lembaga pendidikan untuk mewujudkan tujuan, visi, dan misi lembaganya (Tilaar 2000). Dalam kaitanyya dengan kurikulum pesantren Azyumardi Azra mengatakan dalam tulisan beliau yang di muat di Bloomsburry academic: 
"Educational reform in Indonesia can be attributed to several factors, the fist being the openness of the Islamic educational institutions to reform their curriculum, of special mention are the reform that took place in the pesantrens. While continuing to maintain traditional aspects of educational system, some pesantrens in Java began to modernize certain aspects of their institutions such as management, curricula and the adoptionof the madrasa system" (Azra 2014:61).

Dalam hal ini kurikulum pesantren termasuk kurikulum yang ada di pesantren anak-anak tahfiẓ al-Qur'ân Raudhatul Falah Gembong Pati dibagi menjadi tiga bagian, yaitu kurikulum pendidikan al-Qur'an, kurikulum pendidikan madrasah, dan kurikulum ekstra kurikuler, dan penulis akan menjelaskan secara global. Kurikulum pendidikan al-Qur'an yaitu Pesantren anak-anak tahfiz al-Qurân anak-anak Raudlatul Falah Gembong Pati adalah lembaga pendidikan yang program utamanya adalah pendidikan al-Qur'ân (hafal al-Qur'ân). Dalam pendidikan al-Qứan, materi yang ada adalah meliputi: tashih mahkhroj, tashih huruf, tajwid, dan tahfiz.

Materi-materi tersebut terutama materi tahfiz diselenggarakan lima kali pertemuan dalam setiap hari, waktunya adalah:- selesai sholat subuh untuk menambah hafalan -seleai sholat dhuhur berjama'ah untuk melancarkan hafalan -sehabis sholat ashar berjama'ah untuk melancarkan hafalan -menjelang waktu sholat maghrib untuk evaluasi hafalan al-Qurân- selesai holat maghrib berjama'ah untuk melancarkan hafalan. Adapun teknik pelaksanaannya adalah secara klasikal, masing-masing kelompok diasuh oleh seorang ustadz. Untuk pembagian kelompok kelompok ini didasarkan kepada jumlah juz yang telah dihafal, sedangkan prosesnya adalah semua santri satu persatu menghadap ustadz untuk membacakan al-Qur'ân baik itu secara bi an-nadhor yaitu dengan membaca langsung pada mushaf maupun secara bi al-ghaib (hafalan).

Pelaksanaan adanya tashih makhroj, tashih huruf dan tashih tajwid tergabung dalam kurikulum yang dijelaskan dalam buku pengajaran, yaitu buku-buku tajwid yang digunakan di madrasahmadrasah, termasuk madrasah tahfîz Raudhatul Falâh Bermi Gembong Pati. Penerapan kurikulum pendidikan al-Qurân itu 
dilaksanakan dalam madrasah yang ada di dalam kelas baik itu kelas I samapai kelas VI dan waktunya memang tidak banyak namun cukup untuk mengajarkan kitab tajwid pada para santri, sedangkan dalam praktek pembacaan dan pengahafalan al-Qur'ân itu dipraktekkan dalam pengajaran al-Qur'ân yang dilaksanakan diluar jam sekolah, dan dalam kegiatan ini santri dapat mempraktekkan makhârij alkhurûf dan pentashihan huruf kepada ustadz al-Qur'ân, sedangkan dalam pentashihan hafalan dilaksanakan setelah praktek makhroj dan pentashihannya selesai dengan baik, dengan mengulang bacaanbacaan al-Qur'an samapai benar. Sedangkan kurikulum pendidikan ekstra kurikuler yang diterapkan di pesantren anak-anak tahfiz alQư'ân Raudlatul Falâh Bermi Gembong Pati adalah kurikulum yang dibuat oleh kalangan pesantren sendiri, ada dua macam bantuk yaitu, kurikulum yang bersifat edukatif dan bersifat hiburan.

\section{Metode Pendidikan}

Salah satu komponen penting untuk mencapai keberhasilan pendidikan dalam mencapai tujuan adalah ketepatan menentukan metode, sebab tidak mungkin materi pendidikan dapat diterima dengan baik kecuali disampaikan dengan metode yang tepat. Metode diibaratkan sebagai alat yang dapat digunakan dalam suatu proses pencapaian tujuan, tanpa metode, suatu materi pelajaran tidak akan dapat berproses secara efesien dan efektif dalam kegiatan belajar mengajar menuju tujuan pendidikan.

Metode pendidikan yang tidak tepat guna akan menjadi penghalang kelancaran jalannya proses belajar mengajar, sehingga banyak tenaga dan waktu terbuang sia-sia. Oleh karena itu metode yang diterapkan oleh seorang guru, baru berdaya guna dan berhasil guna jika mampu dipergunakan untuk mencapai tujuan pendidikan yang ditetapkan. Dalam pendidikan Islam, metode yang tepat guna bila ia mengandung nilai nilai yang instrinsik dan ekstrinsik sejalan dengan materi pelajaran dan secara fungsional dapat dipakai untuk merealisasikan nilai-nilai ideal yang terkandung dalam tujuan pendidikan Islam.

Muhaimin Zein membagi metode menghafal al-Qur'ân menjadi dua macam yaitu metode tahfìz dan tikrâr. Tahfîz yaitu menghafal materi baru yang belum pernah dihafal, sedangkan tikrâr 
yaitu mengulang hafalan yang sudah diperdengarkan kepada guru atau instruktur (Zein 1985:248). Sedangkan menurut Abdul-Rabb Nawabuddîn dalam kitabnya yang berjudul kayfa Tuhfazul Qur'ân al-Karîm, beliau membagi metode menghafal al-Qur'ân menjadi dua bentuk, yaitu metode global dan rinci (Nawabuddin 1992:36).

Menghafal al-Qur'ân dapat diartikan sebagai proses menghafal al-Qur'ân dalam ingatan sehingga dapat dilafazkan/diucapkan di luar kepala secara benar dengan cara-cara tertentu secara terusmenerus (Nawabuddin 1992). Dari pengertian ini ada dua hal pokok pengertian menghafal al-Qur'ân sebagaimana disebut Abd al-Rabbi Nawabuddîn, yaitu: pertama, seorang yang menghafal dan kemudian mampu melafazkan dengan benar sesuai hukum tajwid harus sesuai dengan mushaf al-Qur'ân. Kedua seorang penghafal al-Qur'ân senantiasa menjaga hafalannya secara terus menerus dari lupa, karena hafalan al-Qur'ân itu sangat cepat hilangnya. Orang yang telah hafal sekian juz al-Qur'ân kemudian tidak menjaganya, maka dia tidak disebut seorang hafiz al-Qur’ân, karena tidak menjaganya secara terus menerus.

Sedangkan metode yang dimaksud dalam penelitian adalah metode pendidikan yang dimaksudkan di dalam penelitian ini adalah metode pendidikan al-Qur'ân yaitu cara yang dipakai dalam mengajarkan al-Qurân. Atau dikatakan cara yang teratur dan terpikir baik-baik untuk mencapai kerja yang bersistem untuk memudahkan pelaksanaan kegiatan guna mencapai tujuan yang ditentukan. Jadi metode yang dimaksud di dalam penelitian ini adalah cara-cara yang digunakan oleh para ustadz al-Qur'ân dalam mengajarkan alQur'ân kepada para santri dan juga oleh para santri dalam menghafal al-Qur'ân, karenanya metode merupakan faktor yang mempunyai peranan penting dalam usaha untuk mencapai terget yang baik yang bersifat kualitatif maupun kuantitatif.

Metode-metode yang diterapkan pesantren anak-anak tahfiz al-Qur'ân Raudhatul Falâh Bermi Gembong Pati para santri untuk menghafal al-Qur'ân dalam sistem pendidikan secara umum berbeda dengan metode-metode yang diberlakukan dalam kegiatan belajar mengajar sistem formal seperti di madrasah, perbedaan ini dikarenakan adanya perbedaan tentang materi dan tujuan pembelajaran. Metodemetode untuk menghafal al-Qur'ân yang digunakan dan berlaku di 
pesantren anak-anak tahfiz al-Qurân Raudhatul Falâh Gembong Pati semuanya disusun oleh yayasan Raudlatul Falâh, artinya bahwa semua aktifitas santri dalam belajar mengahafal al-Qurân hanya mengikuti dan melaksanakan aturan dan jadwal yang telah disusun oleh yayasan Raudlatul Falah dalam hal ini para pengurus yang jadi pimpinannya adalah KH. Jaelani. Metode-metode yang diterapkan pada santri anak-anak Raudlatul Falâh adalah sebagai berikut:

\section{a. Metode Musyafahah}

Metode Musyafahah adalah metode belajar mengahafal alQur'ân yang antara ustadz dengan santri terlibat dan berkumpul dalam satu majlis yang selanjutnya memberikan materi hafalan kepada santri secara satu persatu. Adapun praktek dari metode ini adalah guru (ustadz) terlebih dahulu membacakan ayat-ayat yang akan dihafal oleh santri kepada masing-masing santri sampai santri dapat dapat menirukan dengan baik dan benar, kemudian langkah selanjutnya adalah santri membaca bi al-nazar (dengan melihat) ayat-ayat sudah dibacakan oleh ustadz dengan tetap didengarkan secara langsung oleh ustadz.Metode musyafahah dalam proses belajar mengajar menghafal al-Qurân mempunyai peranan yang besar terhadap kualitas hafalan santri, karena pada penggunaan metode ini santri hanya mengambil bacaan dari ustadz secara apa adanya.

\section{b. Metode Setor}

Istilah setor dalam aktifitas mengahafal al-Qur'ân adalah memperdengarkan hafalan-hafalan baru kepada ustadz. Kegiatan setor ini wajib dilakukan oleh semua antri yang menghafal alQur'an, karena pada waktu setor inilah maka hafalan santri disimak oleh ustadz sehingga dengan metode setor, hafalan santri juga dapat terpelihara kebenarannya. Kegiatan setor hafalan al-Qứân di pesantren Raudhatul Falâh Gembong Pati secara umum materi dan caranya adalah sama dengan pondok pesantren huffaz dewasa atau pondok huffaz lainnya. Adapun caranya adalah santri secara satu peratu memperdengarkan hafalan-hafalan baru yang telah dihafalnya kepada ustadz, sebelum sampai kepada tahap setor hafalan, terlebih dahulu bacaan santri harus disimak/didengar oleh ustadz, pada langkah ini santri membacanya adalah dengan melihat pada mushaf langsung (bin nazar) yang biasanya setelah sholat jama'ah sholat subuh. Kegiatan wajib setor hafalan bagi santri ini rata-rata 
santri menyetor hafalannya setengah halaman penuh, dan banyak sampai satu satu setengah halaman. Kemampuan setor hafalan bagi santri sangat beragam sehingga banyak banyak sedikitnya setor tidak dibatasi, tetapi semua itu diesuaikan dengan kemampuan hafalan santri sandiri. Setor hafalan memang merupakan kegiatan rutinitas harian pesantren anak-anak tahfiz al-Qur'ân Raudhatul Falâh Bermi Gembong Pati, namun dalam prakteknya terkadang seorang santri juga pernah mengalami hambatan sehingga ia tidak dapat melakukan setor hafalan. Menanggapi masalah tersebut maka jalan keluarnya adalah dengan menunda setor pada hari berikutnya atau dengan melakukan takrir (pengulangan) hafalannya. Namun jika ketidakmampuan setor hafalan itu disengaja oleh santri dan melebihi tiga hari maka akan diberlakukan sanksi atau hukuman yang sifatnya mendidik yang antara lain adalah penambahan hafalan dan memperbanyak materi takrir.

\section{c. Metode Takrir atau Tikrar}

Metode takrir adalah suatu metode mengulang hafalan yang sudah diperdengarkan kepada ustadz yang fungsinya adalah untuk menjaga agar materi yang sudah dihafal tidak terjadi kelupaan. Tikrâr, yaitu mengulang hafalan atau mensima'kan hafalan yang pernah dihafalkan/sudah pernah disima'kan kepada guru tahfîz. Tikrâr dimaksudkan agar hafalan yang pernah dihafal tetap terjaga dengan baik. Selain dengan guru, tikâr juga dilakukan sendiri-sendiri dengan maksud melancarkan hafalan yang telah dihafal, sehingga tidak mudah lupa. Misalnya pagi hari untuk mengahafal materi hafalan baru, dan sore harinya untuk men-takrîr materi yang telah dihafalkan (Sa'dullah 2009:52-54).

Metode takrir atau disebut dengan metode driel (latihan) adalah suatu metode dalam pendidikan dan pengajaran yang sudah diberikan. Dalam pendidikan agama, metode ini sering dipakai untuk melatih ulangan pelajaran al-Qư'ân dan praktik ibadah (Zuhairini 1983:106). Untuk itu metode hafalan ini tepat untuk menjaga dan memperlancar hafalan, namun hafalan yang sudah diperdengarkan kepada ustadz yang semula sudah dihafal dengan baik dan lancar, kadang kala masih terjadi kelupaan lagi bahkan kadang-kadang menjadi hilang sama sekali, oleh karena itu perlu diadakan takrir atau mengulang kembali hafalan yang telah diperdengarkan kepada para ustadz tadi (Zein 1985). 
Sewaktu takrir, materi yang diperdengarkan ke hadapan ustadz harus selalu seimbang dengan tahfizh yang sudah dikuasainya. Jadi tidak boleh terjadi bahwa takrir jauh ketinggalan dari tahfiznya. Dalam hal ini pertimbangan antara tahfiz dan takrir adalah satu banding sepuluh, artinya apabila penghafal mempunyai kesanggupan hafalan baru atau tahfiz dalam satu dari dua halaman, maka harus diimbangi dengan takrir dua puluh halaman (satu juz). Tepatnya materi tahfiz satu juz yang terdiri dari dua puluh halaman, harus mendapat imbangan takrir sepuluh kali, demikianlah seterusnya.

Pelaksanaan metode takrir di pesantren anak-anak tahfiz alQư'ân Raudlatul Falâh Bermi adalah pada setiap kali setor, sehingga terdapat perbandingan antara materi yang disetor dengan materi yang ditakrir. Posisinya adalah sebelum santri setor hafalan atau memperdengarkan tambahan hafalan, frekwensi takrir ini bervariasi disesuaikan dengan kemampuan setor hafalannya dan rata-rata santri mentakrir seperempat juz atau empat halaman. Adapun untuk bahan takrir yang tidak masuk dalam materi setor maka hal itu disesuaikan dengan banyaknya yang telah dihafalnya. Takrir ini adalah takrir harian, takrir harian ini dirinci dengan rincian bagi santri yang jumlah hafalannya antara 1-10 juz maka materi takrirnya antara seperempat atau setengah juz, sedangkan santri yang hafalannya telah mencapai 20 juz maka materi takrirnya adalah antara setengah sampai satu juz atau antara 10-20 juz halaman, dan untuk santri yang telah mencapai 10 juz terakhir sampai yang sudah hatam maka materi takrirnya adalah 1 juz atau lebih.

\section{Sarana Pendidikan}

Sarana pendidikan yang ada di pondok pesantren anak-anak tahfiẓ al-Qur'ân Raudlatul Falâh Bermi Gembong Pati Jawa Tengah meliputi banyak ragam dan aspeknya, meliputi masjid, tempat asrama, aula, sarana olah raga, perpustakaan, ruang laboratorium komputer dan lain-lain, gedung Asrama, masjid, sarana olah raga dan bermain, sarana kesehatan santri, toko koperasi, sarana komputer dan perpustakaan.

Sistem pendidikan yang diterapkan di Pesantren anakanak tahfiz al-Qurân Raudhatul Falâh Bermi Gembong Pati yang menggunakan sistem pesantren dan sistem madrasah dalam arti 
sistem yang memadukan semua komponen mulai dari tempat ibadah (masjid), tempat pemondokan santri atau asrama, sarana olahraga, sarana tempat kesehatan, tempat penginapan, tempat sekolah santri, tempat penginapan ustadz dan perpustakaan. Semua komponen itu menjadi satu bangunan asrama, jadi mudah untuk mengatur dan mengontrol terutama bagi pengasuh santri. Kalau dilihat dari kaca mata pendidikan telah memenuhi kriteria standar dari sistem pendidikan nasioanal karena telah menghasilkan lulusan (output) yang diharapkan.

Sistem pendidikan pesantren yang diterapkan di pesantren anak-anak tahfiż al-Qur'ân anak-anak Raudhatul Falâh Bermi Gembong Pati dengan menggunakan sistem pesantren diterapkan pada pengajaran al-Qur'an dengan dihafal dan sistem klasikal yang diterapkan pada pendidikan madrasah. Sistem pengajaran al-Qurân yang menggunakan metode sorogan dan sistem pendidikan madrasah memggunakan metode klasikal.

Siswa atau santri yang baik yang menghasilkan out put yang baik pula tentunya tidak terlepas dari faktor pendidik dan anak didik. Ketika sistem pendidikan yang baik dijalankan dengan begitu baik dan faktor pendidik dan anak didik yang benar-benar dapat menerima sistem pendidikan tersebut maka hubungan keduanya sangat erat dan kuat. Perlu diketahui bahwa anak didik atau peserta didik benar-benar diseleksi dengan ketat, begitu juga dengan para pendidiknya, baik itu ustadz al-Qurân MI, maupun murabbi (pengasuh). Penseleksian peserta didik atau anak didik dilaksanakan pada awal pendaftaran dan anak yang diterima sanggup memenuhi kriteria yaitu sebagai berikut: harus berumur 6/7 tahun, dapat membaca huruf hijaiyyah (al-Qur'ân), dikarantina tiga bulan di pasantren tanpa ditemani orang tua maupun saudara, tidak boleh ngompol saat tidur atau sudah tamyiz, sanggup menghafal al-Qur'ân dan sekolah di MI, pendaftaran dibatasi, pesantren hanya menerima 30 santri pertahun.

Pengamatan ini pada pengajaran al-Qurân dengan hafalan, banyak santri yang mudah menghafal sampai kelas 4 MI saja telah menghatamkan al-Qur'ân 30 juz bil gaib, tetapi yang banyak sampai kelas 6 MI. Karena memang faktor kecerdasan dan kedisiplinan santri dalam menghafal yang mempengaruhi cepat tidaknya santri dalam menghafal. Kalau melihat dua sistem pendidikan yang diterapkan 
di peasantren anak-anak tahfiẓ al-Qurân Raudlatul Falâh Bermi Gembong Pati, santri dituntut mandiri untuk dapat mengikuti pendidikan dengan baik dan mentaatinya, karena tidak menutup kemungkinan setiap tahun ada santri yang keluar dari pesantren dengan alasan tidak kuat dalam menghafal al-Qurân dan banyaknya pelajaran MI, alasan tidak betah dan tidak tahan tinggal di pesantren, alasan orang tua tidak tega melihat anaknya tidak terurus, alasan anak malas dan belum mampu untuk menghafal. Faktor-faktor ini semua yang mengakibatkan para pengurus berfikir lebih serius bagaimana menghadapi faktor tersebut. Hal di atas merupakan tantangan bagi pendidik terutama ustadz al-Qur'ân karena sebagian besar waktu dipergunakan untuk belajar menghafal al-Qur'an.

Pendidik di Pesantren anak-anak tahfiz al-Qurân Raudhatul Falâh Bermi Gembong Pati benar-benar santri dewasa yang senior yang lama pengabdiannya khususnya ustadz al-Qur'an. Rata-rata pendidik usianya di atas 25 tahun namun tidak ada dari mereka yang bergelar sarjana hanya tamatan aliyah atau pesantren, sedangkan murabbi sebagian dari pondok pesantren alumni Yanbu' al-Qur'ân Kudus. Gambaran sistem pendidikan yang ada di pesantren cukup baik, karena setelah melihat hasil yang dicapai telah memenuhi target atau tujuan yang ingin dicapai. Sedangkan secara mikro, sistem kegiatan belajar mengajar diprogramkan ke dalam struktur kurikulum baik dalam materi, metode dan tujuannya. Antara materi, metode dan tujuan pendidikan harus saling berkaitan dan berusaha saling mengembangkan sehingga benar-benar efektif (tepat guna) dan efisien (berhasil guna) yang konsisten dan relevan dengan tujuan akhir pendidikan Islam. Pendidikan al-Qứân dengan hafalan menggunakan kurikulum sendiri, antara kurikulum, metode dan tujuan serta sarana pendidikan kalau dilihat dari sistem pendidikan telah memenuhi syarat dan haru mendukung dan menghasilkan tujuan yang diharapkan dan dicapai.

Tujuan pendidikan pesantren harus didukung dan ditopang oleh semua komponen yang lainnya, karena tujuan adalah faktor yang sangat penting dalam suatu proses, hal ini karena tujuan itu akan mampu mengarahkan semua aktifitas dalam proses dan bentuk aktifitas yang perlu dilakukan sehingga pencapaian tujuan adalah buah dari aktifitas. Sedangkan tujuan pendidikan pesantren anak- 
anak tahfiz Raudlatul Falah Bermi Gembong Pati sebagai tujuan utama, di samping juga pendidikan madrasah yang akan mencetak seorang hafiz yang berpengetahuan luas. Karena pentingnya tujuan menghafal al-Qur'ân tersebut maka hendaknya penanaman al-Qur'ân itu dilakukan sejak dini. Dengan penanaman al-Qur'ân sejak dini maka diharapkan akan mendapat nilai keimanan dari al-Qur'ân sampai anak tersebut menjadi dewasa. Dengan adanya tujuan yang harus dicapai maka materi, metode dan sarana harus dapat mendukung dan mengantarkan tujuan tersebut sesuai dengan harapan.

Sedangkan untuk sarana pendidikan yang ada di pesantren anak-anak tahfiẓ al-Qur'ân Raudhatul Falâh Gembong Pati dapat dikatakan cukup lengkap dan memadahi yang meliputi berbagai fasilitas pendidikan seperti perpustakaan, ruang komputer, masjid, sarana olah raga, sampai asrama santri. Sarana pendidikan dengan fasilitas yang memadai dapat dikatakan sebagai sarana sekolah unggulan dengan catatan bahwa perekrutan siswa yang sangat selektif berdasarkan kapasitas intelektual dan pertimbangan lain yang melingkupinya serta dengan kurikulum yang ideal (Azra 1999:7376). Mengenai sarana pendidikan tentunya harus mendukung tujuan pendidikan yang diharapkan, karena semua situasi dan kondisi pendidikan yang secara intensional dan sistematis diadakan untuk mendukung perbuatan mendidik, ditujukan untuk memberikan pengaruh edukatif dan juga segala macam sistem peralatan dan alatalat bantu yang sengaja diadakan untuk memperlancar pencapaian tujuan pendidikan.

\section{Simpulan}

Berdasarkan pembahasan di atas dapat ditarik simpulan adalah merujuk pada rumusan masalah dan tujuan penelitian yang telah dijelaskan dalam bab pertama. Dari seluruh uraian yang dipaparkan terdahulu, dapat ditarik simpulan yaitu:

Pertama; Sistem pendidikan yang diterapkan dipesantren anak-anak tahfị al-Qur’an Raudhatul Falah Bermi Gembong Pati adalah: yang pertama pendidikan tahfiz (menghafal) al-Qur'an 30 juz bil ghaib sebagai pendidikan formal yaitu pendidikan informal dan yang utama, kedua, pendidikan formal yaitu pendidikan agama Islam yaitu Madrasah Ibtidaiyah, ketiga, pendidikan ekstra kurikuler 
(tambahan), yaitu pendidikan yang memperkuat kedua pendidikan diatasnya, ditambah dengan olahraga dan hiburan.

Kedua; Sistem yang dibangun di pondok pesantren tersebut meliputi dari tujuan, pendidik, anak didik, metode, kurikulum, dan sarana hampir semua ada kesamaan, namun yang membedakan adalah penekanan pada penghafalan al-Qur'ân. Dalam pelaksanaan pendidikan di Pesantren anak-anak tahfiz al-Qur'ân anak-anak Raudhatul Falâh Bermi Gembong Pati menekanan pada penghafalan al-Qur'ân adalah bersifat mutlak, sehingga ada tuntutan bagi santri untuk menghatamkan hafalannya pada masa yang relatif cukup cepat antara 4 sampai 5 tahun, namun juga ada yang terlambat sampai 5 tahun karena disebabkan kurangnya kecerdasan santri dan kekuarangnyamanan hidup di pesantren.

Dari beberapa temuan dan simpulan yang diperoleh dari penelitian ini, penulis mengemukakan beberapa saran dan usulan sebagai sumbangan pemikiran untuk memperbaiki, meningkatkan bahkan memperbaruhi sistem pendidikan yang ada di pesantren anak-anak tahfiz al-Qur'ân Raudlatul Falâh Bermi Gembong Pati Jawa Tengah, saran tersebut adalah sebagai berikut:

Kepada pihak kyai dan ustadz, pengurus pesantren anak-anak tahfiz al-Qứân Raudlatul Falâh Bermi Gembong Pati Jawa tengah, diharapkan bahwa sistem pendidikan yang ada dipesantren tetap dipertahankan dengan baik, dan perlu peningkatan dalam kurikulum yang sangat menunjang emosi dan kreatifitas anak, sehingga bakat dan potensi yang dimiliki oleh anak tidak hilang begitu saja, di samping itu perlu adanya hiburan atau musik yang dimasukkan dalam kegiatan pendidikan yang akan merangsang otak anak agar tidak berat sebelah atau seimbang.dari segi kesehatan pengurus harus bekerja keras bagaimana mengurusi anak agar kesehatan dan kenyamanan anak terjamin secara keseluruhan, meskipun melalui proses yang tidak pendek. Hal itu semua adalah untuk kebaikan dan peningkatan pesantren supaya menjadi pesantren anak-anak yang ideal.

Kepada pada pendidik. Para pendidik agar lebih banyak belajar dan mengetahui dunia pendidikan khususnya pendidikan anak-anak, karena perubahan zaman yang begitu global dan modern, maka pendidik dituntut tahu dan mengerti bagaimana mengajar dan menghadapi anak yang rata-rata kecerdasannya baik. Hal ini perlu 
adanya peningkatan kualitas pendidik, yaitu caranya menyekolahkan guru ke jenjang yang lebih tinggi, dengan adanya pengarahan dan latihan-latihan bagi guru dengan mendatangkan ahli pendidikan khususnya pendidikan anak. Dengan begitu sedikit demi sedikit aka tahu dan mengerti tentang dunia pendidikan anak.

Kepada para peneliti. Para peneliti diharapkan ikut berusaha untuk mencari formulasi baru untuk meningkatkan sistem pendidikan di pesantren ank-anak tahfiz anak-anak Raudhatul Falâh Gembong Pati Jawa tengah dan mencari kekurangan dan kelemahan yang ada di pesantren sehingga dengan begitu sedikit demi sedikit kekurangan itu dapat tertutupi, sehingga anak-anak yang keluar dari pesantren ini benar-benar menjadi santri yang handal dan berkualitas. 


\section{DAFTAR PUSTAKA}

Arikunto, Suharsimi. 1989 Prosedur Penelitian. Jakarta: Bina Aksara. Azra, Azyumardi. 1999. Pendidikan Islam Tradisi Dan Modernisasi Menuju Millenium Baru. Jakarta: Logos.

2014 Reform in Islamic Education : A Global Prespective Seen from the Indonesian Case. India: Great Britain.

Dokumentasi,Pesantren. 2016. Dokumentasi Pesantren Tahfiz AnakAnak Raudhatul Falah Bermi Gembong Pati. Pati.

Dokumentasi Pesantren Raudhatul Falah Bermi Gembong Pati. 2016

Hayat, Bahrul, and Muhammad Ali. 2012. Khazanah Dan Praksis Pendidikan Islam Di Indonesia. Jakarta: Pustaka Cendekia Utama.

Hurlock, Elizabeth.B. 1997. Perkembangan Anak. Jakarta: Erlangga.

Masri Singarimbun, Efendi, and Sofiyan. 1989 Metode Penelitian Survei. Jakarta: LP3ES.

Moleong,Lexy. 2001 Metodologi Penelitian Kualitatif. Bandung: Remaja Rosdakarya.

Muthohar,Ahmad. 2007 Ideologi Pendidikan Pesantren: Pesantren Di Tengah Arus Ideplogi-Ideologi Pendidikan. Semarang: Pustaka Rizki Putra.

Nasution. 1988. Metode Penelitian Naturalistik Kualitatif. Bandung: Tarsito.

Nawabuddin, Abd al-Rabbi. 1992 Metode Efektif Menghafal AlQur'an. Jakarta: Tri Daya Inti.

Nugroho, Puspo. 2019. Manajemen Lembaga Pendidikan Islam Non Formal "Satu Atap" Al Hidayah Juranggunting Argomulyo Kota Salatiga. Quality: journal of empirical research in Islamic education 7(1): 1-28.

Prayitno,Prima. 2016 Pemberdayaan Sumber Daya Santri Melalui Entrepreneurship Di Pondok Pesantren Al-Ashriyah Nurul Iman Islamic Boarding School Parung-Bogor. Jurnal Quality: Jurnal Pendidikan Islam 4(2). 
Sa'dullah. 2009.Cara Cepat Menghafal Al-Qur'an. Jakarta: Gema Insani.

Sanjaya, Wina. 2009 Kurikulum Dan Pembelajaran Teori Dan Praktik Pengembangan Kurikulum Tingkat Satuan Pendidikan. Jakarta: Kencana Prenada Media Group.

Tilaar, H.A.R. 2000. Paradigma Baru Pendidikan Nasional. Jakarta: Rineka.

Waluyo, Hasan. 1988. Petunjuk Pelaksanaan Kurikulum Taman Kanak-Kanak. Jakarta: Departemen Pendidikan dan Kebudayaan RI.

Zein,Muhaimin. 1985 Tata Cara/Problematika Menghafal AlQur'an Dan Petunjuk-Petunjuknya. Jakarta: Pustaka AlHusna.

Zuhairini. 1983. Metodik Khusus Pendidikan Agama Dilengkapi Dengan Sistem Modal Dan Permainan Simulasi. Surabaya: Usaha Nasional. 
Ahmad Falah 